\title{
Physiological and growth response of rice plants (Oryza sativa L.) to Trichoderma spp. inoculants
}

\author{
Febri Doni ${ }^{1 *}$, Anizan Isahak ${ }^{2}$, Che Radziah Che Mohd Zain ${ }^{1}$ and Wan Mohtar Wan Yusoff ${ }^{1}$
}

\begin{abstract}
Trichoderma spp., a known beneficial fungus is reported to have several mechanisms to enhance plant growth. In this study, the effectiveness of seven isolates of Trichoderma spp. to promote growth and increase physiological performance in rice was evaluated experimentally using completely randomized design under greenhouse condition. This study indicated that all the Trichoderma spp. isolates tested were able to increase several rice physiological processes which include net photosynthetic rate, stomatal conductance, transpiration, internal $\mathrm{CO}_{2}$ concentration and water use efficiency. These Trichoderma spp. isolates were also able to enhance rice growth components including plant height, leaf number, tiller number, root length and root fresh weight. Among the Trichoderma spp. isolates, Trichoderma sp. SL2 inoculated rice plants exhibited greater net photosynthetic rate (8.66 $\mu$ molCO $\mathrm{m}^{-2} \mathrm{~s}^{-1}$ ), internal $\mathrm{CO}_{2}$ concentration (336.97 ppm), water use efficiency $\left(1.15 \mu \mathrm{moCO} / 2 \mathrm{mmoH}_{2} \mathrm{O}\right)$, plant height $(70.47 \mathrm{~cm})$, tiller number $(12)$, root length $(22.5 \mathrm{~cm})$ and root fresh weight $(15.21 \mathrm{~g})$ compared to the plants treated with other Trichoderma isolates tested. We conclude that beneficial fungi can be used as a potential growth promoting agent in rice cultivation.
\end{abstract}

Keywords: Trichoderma spp; Rice; Physiological response; Growth response

\section{Introduction}

Rice growth is influenced by a combination of genotype, environment and management factors. Balancing and improving soil fertility is one of the main factors in enhancing rice growth and yield. The intensive cultivation of rice that depends on chemical fertilizers and pesticides have led to the decrease in soil fertility and deteriorating soil health. The excessive use of chemical fertilizers in the current decades has led to soil toxicity through the presence of toxic heavy metals and adversely affecting the health of rice plants (Habibah et al. 2011). To overcome the decrease in soil fertility and deterioration in soil health caused by the use of chemical fertilizers, it is necessary to look for alternative ways to improve soil fertility and stimulate the growth of rice plants.

Microbes have been reported to be a key factor in maintaining soil quality and increasing rice yield and growth. The use of microbes to enhance rice growth while making the plant resistant to pathogens has been

\footnotetext{
*Correspondence: doni@siswa.ukm.edu.my

'School of Biosciences and Biotechnology, Faculty of Science and Technology, Universiti Kebangsaan Malaysia, 43600 Bangi, Selangor, DE, Malaysia

Full list of author information is available at the end of the article
}

reported as an eco-friendly way to maintain the ecosystem. For decades, the application of microbes in a sustainable agroecological manner has increased rapidly due to their ability to act as plant growth promoters (Sakthivel and Gnanamanickam 1987; Carreres et al., 1996; Malik et al., 1997; Anhar et al., 2011; Pedraza et al., 2009; Amprayn et al., 2012; Anizan et al., 2012).

Trichoderma spp. recently was suggested as a Plant Growth Promoting Fungi (PGPF) due to their ability to produce siderophores, phosphate-solubilizing enzymes, and phytohormones (Doni et al., 2013). Trichoderma species play important roles in decomposition, mycoparasitism, and even in cellulose degradation (Jiang et al., 2011; Druzhinina et al., 2006; Samuels, 1996). Trichoderma spp. was reported to be able to increase growth in plants such as strawberries, tomatoes, soya beans, apples, cotton and gray mangroves (Saravanakumar et al., 2013; Raman, 2012; John et al., 2010; Shanmugaiah et al., 2009; Morsy et al. 2009; Porras et al., 2007). However, very little research has been conducted on the potential of Trichoderma spp. for improving rice growth.

Recently, we reported the successful isolation of several Trichoderma spp. and which have been proven to 
possess positive plant growth promotion potential in enhancing rice seed germination and vigour (Doni et al., 2014). This research was conducted to examine the effect of Trichoderma spp. on rice growth and physiological response.

\section{Materials and methods}

This experiment was conducted at the Fermentation Technology Laboratory, Genetics Molecule Laboratory and Greenhouse, School of Biosciences and Biotechnology, Faculty of Science and Technology, Universiti Kebangsaan Malaysia. A completely randomized design (with nine treatments and three replications) was used for this experiment. Rice plants were placed in soil with different Trichoderma spp. inoculants and soil with NPK fertilizer $100 \mathrm{~kg} \mathrm{ha}^{-1}$. The NPK fertilizer used is in accordance to the rate employed in Micheal et al., (2013) for rice variety MRQ74. Sterilized soil without any application was used for control.

\section{Trichoderma spp. inoculants preparation}

Local isolates of Trichoderma spp. which was isolated from System of Rice Intensification Paddy Field, Sik, Kedah, Malaysia namely Trichoderma sp. SL1, Trichoderma sp. SL2 (Public Accession number: UPMC 1021), Trichoderma $s p$. SL3, Trichoderma sp. SL4, Trichoderma sp. SL5, Trichoderma sp. SL6 and Trichoderma sp. SL7 were obtained from the Fermentation Technology Laboratory, School of Biosciences and Biotechnology, Faculty of Science and Technology, Universiti Kebangsaan Malaysia. Each isolate was grown separately in potato dextrose broth and incubated for seven days in a thermo shaker at a speed of $200 \mathrm{rpm}$ and $30^{\circ} \mathrm{C}$. After incubation, Trichoderma spp. inoculants were filtered using filter paper and stored in sterile polyethylene plastic bags.

\section{Soil preparation and Trichoderma spp. inoculation}

Autoclaved homogenous sandy clay loam soils were used for this experiment; the dosage of Trichoderma spp. inoculants was set at $5 \mathrm{~g}$ per $1 \mathrm{~kg}$ soil. The inoculated soil was immediately placed in $15 \times 15 \mathrm{~cm}$ plastic containers.

\section{Rice plant preparation}

Rice seeds of the variety MRQ74 were surface sterilized with $70 \%$ ethanol, followed by $5 \%$ sodium hypochlorite and washed by sterilized distilled water. The rice seeds were grown in autoclaved sandy clay loam soil under green house condition with $30 \pm 4^{\circ} \mathrm{C}$ temperature, $320 \pm$ $3 \mu \mathrm{mol}$ light intensity, $80 \pm 3 \%$ humidity and $11 \mathrm{~h} 11 \mathrm{~m}$ $17 \mathrm{~s} \pm 9 \mathrm{~s}$ photoperiod, and placed in a seedling tray. Seven day-old rice seedlings of MRQ74 were transplanted singly in $15 \times 15 \mathrm{~cm}$ plastic containers containing different Trichoderma spp. treatments, NPK treatment and control. Water was maintained at $2 \mathrm{~cm}$ level from the soil surface and actively aerated by physically disturbing and breaking-up the soil surface once every ten days.

\section{Measurement of rice growth and physiological components}

Rice physiological and growth components were measured 30 days after transplanting. Measurements for the physiological characteristics were made on flag leaves. Measurements of net photosynthesis $\left(\mu \mathrm{mol} \mathrm{CO} \mathrm{Cm}^{-2} \mathrm{~s}^{-1}\right)$, leaf stomatal conductance ( $\mathrm{mol} \mathrm{H}_{2} \mathrm{O} \mathrm{m} \mathrm{m}^{-2} \mathrm{~s}^{-1}$ ), and transpiration rate $\left(\mathrm{mmol} \mathrm{H}_{2} \mathrm{O} \mathrm{m}^{-2} \mathrm{~s}^{-1}\right)$ were monitored using a LICOR 6400 portable photosynthesis system (Lincoln, Nebraska, USA) and infrared gas analyser (IRGA). To assess the trade-off between $\mathrm{CO}_{2}$ uptake and water loss, instantaneous water-use efficiency (WUE) was calculated as the ratio between photosynthetic rate and transpiration rate $\left(\mu \mathrm{mol} \mathrm{CO}_{2} / \mu \mathrm{mol} \mathrm{H}_{2} \mathrm{O}\right)$. These measurements were taken on a clear sunny day between 09:45 am until 11:30 am under a saturated light condition (solar radiation $\left.>1200 \mu \mathrm{mol} . \mathrm{m}^{-2} \cdot \mathrm{s}^{-1}\right)$. Plant height $(\mathrm{cm})$ measured from ground level to the tip of the longest leaf, tiller number and leaf number were counted for each treatment and control. For rice root length $(\mathrm{cm})$ and root fresh weight (g) measurements, the rice plants were separated carefully from the soil. Root length was measured from the base of the stem to the longest root using a ruler and root fresh weight was measured using digital scales. Rice root dry weight (g) measurement was done after rice roots were dried in the oven at a temperature of $65^{\circ} \mathrm{C}$ for seven days.

\section{Statistical analyses}

All data were statistically analyzed using one-way analysis of variance (ANOVA). The significance of the effect of the treatment was determined using F-test and to determine the significance of the difference between the means of the treatments, least significant difference (LSD) was calculated at 5\% probability level. Regression relationship was determined using the data analysis SPSS software version 20.

\section{Results}

\section{Rice plant growth performance}

The results of the experiments showed that the treatment of rice plants with Trichoderma spp. has a significant effect on rice plant growth performance (Table 1). Significant increase in plant height was observed for the Trichoderma spp. treated rice plants, registering plant heights in the range of $65.77-70.47 \mathrm{~cm}$ whilst the means for NPK treated rice plants and control were recorded at $28.9 \mathrm{~cm}$ and $63.1 \mathrm{~cm}$ respectively. Significantly greater values for leaf number and tiller number were also observed for Trichoderma spp. treated rice plants. The highest value for leaf number was 38 whilst for tiller number was 13 for the Trichoderma spp. treated plants. 
Table 1 Comparison of plant height, leaf number, tiller number, root length, root dry weight and root wet weight in different treatments

\begin{tabular}{lllllll}
\hline Treatment & Plant height $(\mathbf{c m})$ & Leaf number & Tiller number & Root length $(\mathbf{c m})$ & Root dry weight $(\mathbf{g})$ & Root fresh weight $(\mathbf{g})$ \\
\hline Trichoderma sp. SL1 & $69.23(3.29)$ & $36(3.46)$ & $12(1.53)$ & $21.43(1.440)$ & $2.68(1.39)$ & $9.83(1.73)$ \\
Trichoderma sp. SL2 & $70.47(5.66)$ & $37(4.93)$ & $12(2.65)$ & $22.5(1.76)$ & $4.27(3.33)$ & $15.21(3.20)$ \\
Trichoderma sp. SL3 & $65.77(1.75)$ & $24(2.65)$ & $9(1.15)$ & $15.43(1.10)$ & $1.94(1.13)$ & $8.18(1.68)$ \\
Trichoderma sp. SL4 & $66.47(1.39)$ & $30(5.20)$ & $10(1.73)$ & $17.17(0.65)$ & $2.74(1.28)$ & $11.57(0.49)$ \\
Trichoderma sp. SL5 & $66.50(4.30)$ & $32(2.52)$ & $13(3)$ & $17.37(4.58)$ & $2.74(0.91)$ & $14.8(0.77)$ \\
Trichoderma sp. SL6 & $68.97(3.54)$ & $37(2.65)$ & $11(0)$ & $21.9(2.71)$ & $2.2(0.84)$ & $12.96(3.51)$ \\
Trichoderma sp. SL7 & $67(1.15)$ & $38(3.79)$ & $12(1.73)$ & $21.52(.30)$ & $2.71(0.46)$ & $15.01(3.38)$ \\
NPK & $28.9(0.72)$ & $3(0.58)$ & $1(0)$ & $9.33(0.91)$ & $0.62(0.33)$ & $3.07(0.76)$ \\
Control & $63.1(0.96)$ & $28(1)$ & $8(1.53)$ & $14.57(3.93)$ & $1.94(0.37)$ & $8.51(0.37)$ \\
LSD $_{0.05}$ & 55.46 & 33.08 & 13.02 & 9.18 & $\mathrm{~ns}$ & 9.57
\end{tabular}

ns: Not significant

Standard deviations are given in parentheses $(n=27)$.

On the other hand, the NPK treated rice plant registered 3 leaf number, whilst the control recorded 28. No tiller was observed for the NPK treated rice, whilst the control registered a tiller number of 8 . Root length was found to be significantly increased for the Trichoderma spp. treated rice plants with a range between $17.17-22.5 \mathrm{~cm}$ whilst the NPK treated rice plants recorded root length of only $9.33 \mathrm{~cm}$. For the control, root length was $14.57 \mathrm{~cm}$. Root fresh weight was significantly higher for the Trichoderma spp. treated rice plants as well compared to NPK treated and control. The Trichoderma spp. treated rice plants registered the highest value which was $15.21 \mathrm{~g}$ whilst the root fresh weight for NPK treated plants and control were $3.07 \mathrm{~g}$ and $8.51 \mathrm{~g}$ respectively. Among the Trichoderma $s p$. SL2 treated rice plants showed the greatest increase in plant height, tiller number, root length and root fresh weight, while Trichoderma sp. SL7 had the greatest effect in enhancing the number of leaves. However, no significant improvement in root dry weight was seen for the Trichoderma spp. treated rice plants.

\section{Rice plant physiological characteristic}

The general assessment from this experiment is that the application of Trichoderma spp. to rice plants significantly increased the physiological properties of the rice plants (Table 2). Net photosynthetic rate was high in rice plants inoculated with Trichoderma spp. compared to NPK treatment and control. The range of net photosynthetic rate in rice inoculated with Trichoderma spp. was $6.74-8.79 \mu \mathrm{mol}$ $\mathrm{CO}_{2} \mathrm{~m}^{-2} \mathrm{~s}^{-1}$ while NPK treatment and control recorded values of $2.09 \mu \mathrm{mol} \mathrm{CO} \mathrm{Cm}^{-2} \mathrm{~s}^{-1}$ and $6.21 \mu \mathrm{mol}$ $\mathrm{CO}_{2} \mathrm{~m}^{-2} \mathrm{~s}^{-1}$ respectively. Significantly high values of stomatal conductance were recorded for rice plants inoculated with Trichoderma sp. SL3 and Trichoderma sp. SL6 registering 1237.88 and $1084.76 \mathrm{mmol} \mathrm{H}_{2} \mathrm{O} \mathrm{m}{ }^{-2} \mathrm{~s}^{-1}$ respectively (Table 2). Stomatal conductance for NPK

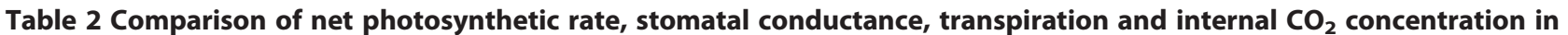
different treatments

\begin{tabular}{|c|c|c|c|}
\hline Treatment & $\begin{array}{l}\text { Net photosynthetic rate } \\
\left(\mu \mathrm{molCO} \mathrm{m}^{-2} \mathrm{~s}^{-1}\right)\end{array}$ & $\begin{array}{l}\text { Stomatal conductance } \\
\left(\mathrm{mmolH}_{2} \mathrm{O} \mathrm{m}^{-2} \mathrm{~s}^{-1}\right)\end{array}$ & $\begin{array}{l}\text { Internal } \mathrm{CO}_{2} \\
\text { concentration (ppm) }\end{array}$ \\
\hline Trichoderma sp. SL1 & $8.79(0.010)$ & $979.08(0.00009)$ & $358.91(0.037)$ \\
\hline Trichoderma sp. SL2 & $8.66(0.007)$ & $412.40(0.00070)$ & $336.97(0.086)$ \\
\hline Trichoderma sp. SL3 & $8.47(0.018)$ & $1237.88(0.0022)$ & $363.79(0.046)$ \\
\hline Trichoderma sp. SL4 & $6.88(0.009)$ & $752.65(0.0024)$ & $358.60(0.023)$ \\
\hline Trichoderma sp. SL5 & $7.38(0.043)$ & 499.54(0.0008) & $348.35(0.172)$ \\
\hline Trichoderma sp. SL6 & $8.60(0.012)$ & $1084.76(0.0014)$ & $361.75(0.039)$ \\
\hline Trichoderma sp. SL7 & $6.74(0.024)$ & 712.38(0.0005) & $361.23(0.076)$ \\
\hline NPK & $2.09(0.007)$ & $340.16(0.0004)$ & $376.69(0.045)$ \\
\hline Control & $6.21(0.016)$ & $818.30(0.0002)$ & $365.74(0.051)$ \\
\hline $\mathrm{LSD}_{0.05}$ & 0.10 & 0.005 & 3.70 \\
\hline
\end{tabular}

Standard deviations are given in parentheses $(n=36)$.

All means were significantly different between treatments at $p<0.05$. 
treatment and control were 340.16 and $818.30 \mathrm{mmol}$

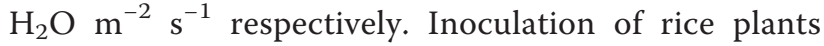
with Trichoderma spp. also significantly influenced the internal $\mathrm{CO}_{2}$ concentration of the rice plants. Results showed that Trichoderma sp. SL2 has the lowest $\mathrm{CO}_{2}$ concentration (Table 2). Rice plants inoculated with Trichoderma spp. significantly enhanced the water use efficiency compared to NPK treatment and control (Figure 1). The highest water use efficiency was observed for Trichoderma sp. SL2 treated plants which registered $1.15 \mu \mathrm{mol}$ $\mathrm{CO}_{2} / \mathrm{mmol} \mathrm{H}_{2} \mathrm{O}$.

\section{Discussion}

\section{Rice plant growth performance}

The benefit of Trichoderma spp. in improving plant growth can be realised through several mechanisms which include mycoparasitism, antibiosis, degradation of toxins, inactivation of pathogenic enzymatic pathways, resistance to pathogens, enhanced nutrient uptake, solubilization, sequestration of inorganic nutrients, and enhanced root hair development (Harman, 2006; Lorito et al., 2010). In this research we tested the ability of Trichoderma spp. to enhance rice growth. The results showed that rice plants inoculated with Trichoderma spp. significantly increased rice growth components. Plant height of Trichoderma spp. inoculated rice plants was higher compared to NPK treatment and control. The ability of Trichoderma spp. to produce phytohormones is the key factor in the increase in rice plant height as reported by Chowdappa et al. (2013). Rice plants treated with Trichoderma spp. also have better nutrient uptake as suggested by Saba et al. (2012). Better nutrient uptake will enhance the physiological processes within the rice plants treated with Trichoderma spp. leading to good growth performance (Figure 2). Leaf number and tiller number were significantly higher in Trichoderma spp. treated rice plants compared to NPK treatment and control. The enhancement of leaf and tiller number by Trichoderma spp. were made possible because of the ability of the Trichoderma spp. to act through several mechanisms such as environmental

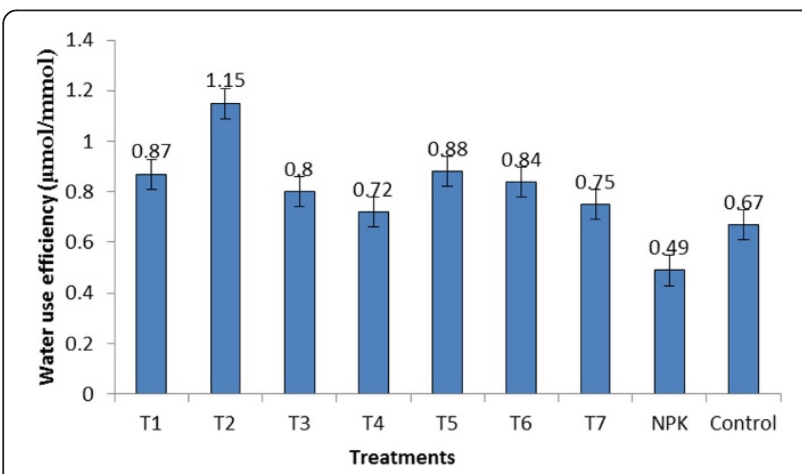

Figure 1 Changes in the water use efficiency by the different treatments.

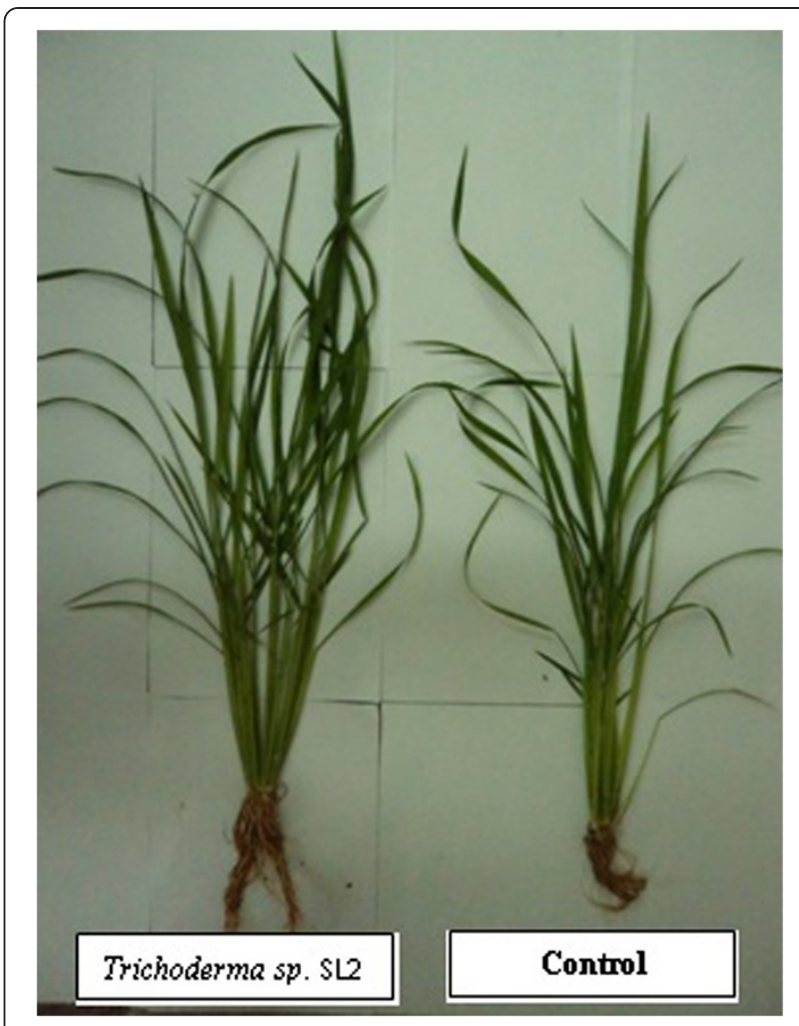

Figure 2 The use of Trichoderma sp. SL2 resulted better growth compared to control.

buffering (against $\mathrm{pH}$, drought, waterlogging, cold and heat), $P$ solubilization and siderophore production (Neumann and Laing, 2006). Furthermore, Shukla et al. (2012) reported that Trichoderma harzianum significantly increased the ability of rice plants to tolerate drought stress and increase rice waterholding capacity. In this research, these mechanisms are believed to be contributing factors that led to higher leaf number and tiller number.

Trichoderma spp. applied to rice plants reported in this research significantly increased rice root length compared to NPK treatment and control (Figure 3). Trichoderma sp. SL2 treated rice plants showed an impressive increase in root length compared to the plants treated with the other strains. Nawrocka and Malolepsza (2013) stated that the ability of Trichoderma spp. hyphae to release elicitors may contribute to signals being transmitted within the plant such as salicylic acid (SA), jasmonic acid (JA) and reactive oxygen species (ROS). Elicitors released by Trichoderma spp. are also involved in triggering expressions of defense protein within the plant (Thakur and Sohal, 2013). In this way, plant immunity against pathogens is induced and in turn improves plant growth. Tchameni et al. (2011) showed that the inoculation of Trichoderma spp. in cacao plants may induce cacao plant resistance against Phytophthora megakarya and increase cacao root length. In addition, Cai et al. (2013) reported that harzianolide 


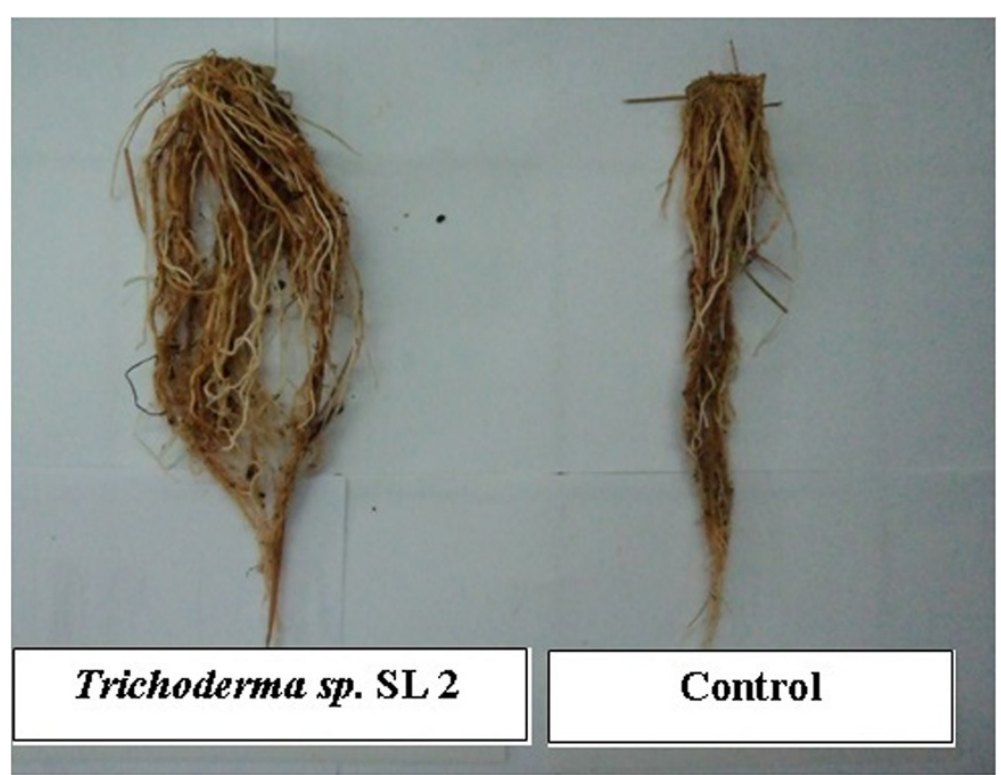

Figure 3 Rice plant root inoculated by Trichoderma sp. SL 2 recorded large mass compared to control.

produced by Trichoderma spp. can improve the early stage of plant development through the enhancement of root length.

The fresh weight of rice root plants treated with Trichoderma spp. was significantly greater than the NPK treated plants and control. However, the weight of dry rice root plants was not significant among treatments. Rice plants inoculated with Trichoderma sp. SL2 have the highest increase in root fresh weight. The capacity of Trichoderma spp. to produce growth hormones such as auxins and gibberelins were reported as the main factor that contributes to the ability of Trichoderma spp. to support root growth and increase water absorption from soil (Arora et al., 1992; Contreras-Cornejo et al., 2009; Martínez-Medina et al., 2011). The present findings are also in agreement with previous research by Viterbo et al. (2010) that revealed the role of Trichoderma asperellum in promoting canola seedling root elongation via ACC deaminase (ACCD) activity.

Our study also reports a lack of response of the rice variety MRQ74 to NPK fertilizer. Recently, research done by Khairiah et al. (2013) revealed that the heavy metal content of the rice variety MRQ 74 plants in chemical fertilizers-used rice field area was high due to excessive usage of NPK fertilizers. Previous research by Yap et al. (2009) also suggested that the use of NPK fertilizers in rice cultivation significantly increase heavy metal content in rice plants. Further, Yadav (2010) stated that heavy metals may cause oxidative stress inside the plants leading to cellular damage. Our research is in agreement with previous researches which revealed the lack response of this variety to NPK fertilizer.

\section{Rice plants physiological characteristics}

Rice growth performance is subjected to environmental factors which affect the physiological processes inside rice plant cells. Improving rice physiological characteristics is considered to be desirable due to its agronomic importance towards the achievement of high rice yield (Makino, 2011; Li et al., 2012). From Table 2, net photosynthetic rates, stomatal conductance, and internal $\mathrm{CO}_{2}$ concentration were significantly different between treatments. High photosynthetic rates were observed for Trichoderma sp. SL1 and Trichoderma sp. SL2. It is known that large amounts of sucrose exudates provided by rice roots to Trichoderma sp. SL1 and Trichoderma sp. SL2 can facilitate good root colonization by Trichoderma spp. as well as promote good coordination of defense mechanism of rice plants (Vargas et al., 2009). The results imply that the root physiological activity of Trichoderma sp. SL2 is the highest among the Trichoderma spp. studied. The results also revealed that Trichoderma $s p$. SL2 has the lowest internal $\mathrm{CO}_{2}$ concentration and the highest photosynthetic rate. This indicates that the activity of carboxylation by $\mathrm{CO}_{2}$ fixation for glucose production as carbohydrate metabolism in the rice plants was very active. The results agree with the findings of Thakur et al. (2010).

Research by Thakur et al. (2010) found that high photosynthetic rates coupled with low transpiration rates indicate high water use efficiency. This report supports our experiment on Trichoderma sp. SL2 which showed high values for these parameters. The activity of Trichoderma spp. that contributes to the enhancement of root growth and distribution was also considered as a key factor to the 
prolonged photosynthetic activity and the delayed senescence in rice plants (Mishra and Salokhe, 2011). Further, Trichoderma spp. was recently reported as having the potential to degrade cellulose (Jiang et al., 2011). Cellulose degradation may release a large amount of $\mathrm{N}$ in rice plant rhizosphere. High $\mathrm{N}$ concentration uptake has positive correlation with photosynthetic rate.

In Figure 2, water use efficiency of Trichoderma $s p$. SL2 was the highest among the Trichoderma spp. isolates registering at $1.15 \mu \mathrm{molmmol}^{-1}$. Stomatal conductance was significantly correlated with photosynthesis. Stomatal conductance plays an importance role in generating photosynthesis in rice plants because $\mathrm{H}_{2} \mathrm{O}$ and $\mathrm{CO}_{2}$ which are involved in photosynthetic process must pass through the stomata before they enter mesophyll cells and chloroplast stroma (Fu et al., 2008). Further, Harman et al. (2004) stated that mechanisms employed by Trichoderma spp. in enhancing nutrient availability by solubilization and chelation of minerals can increase plant metabolism leading to the enhancement of plant physiological activity.

The present study concludes that Trichoderma spp. have the potential to enhance rice physiological processes and growth. In this respect, the present experiment proved that Trichoderma sp. SL2 was the best strain compared to six others strains.

\section{Competing interest}

All the authors declare that they have no competing interest.

\section{Authors' contributions}

FD and Al carried out the green house study and conducted the statistical analysis, and CRCMZ and WMWY drafted the manuscript. All authors read and approved the final manuscript.

\section{Acknowledgments}

We wish to thank Captain Zakaria Kamantasha and Tuan Hj. Marzuki Md. Zin from SRI Lovely, Sik, Kedah, for providing rice seeds for this research. This study was financially funded by Universiti Kebangsaan Malaysia under grant ETP-2013-070, Komuniti-2012-001, Komuniti-2012-007 and DLP-2013-023.

\footnotetext{
Author details

${ }^{1}$ School of Biosciences and Biotechnology, Faculty of Science and Technology, Universiti Kebangsaan Malaysia, 43600 Bangi, Selangor, DE, Malaysia. ${ }^{2}$ School of Environmental and Natural Resources Sciences, Faculty of Science and Technology, Universiti Kebangsaan Malaysia, 43600 Bangi, Selangor, DE, Malaysia.
}

Received: 13 March 2014 Accepted: 4 May 2014

Published online: 29 May 2014

\section{References}

Amprayn K-O, Michael TR, Kecskés M, Pereg P, Nguyen HT, Kennedy IR (2012) Plant growth promoting characteristics of soil yeast (Candida tropicalis HY) and its effectiveness for promoting rice growth. App Soil Ecol 61:295-299

Anhar A, Doni F, Advinda L (2011) Respons pertumbuhan tanaman padi (Oryza sativa L.) terhadap introduksi Pseudomonad flouresen. Eksakta 1(1):1-11

Anizan I, Ahmad A, Rosenani AB, Habibah J (2012) SRI rice crop establishment. Trans Malaysian Soc Plant Physiol 20:11-15

Arora DK, Elander RP, Mukherji KG (1992) Fungal Biotechnology. In: Handbook of Applied Mycology. Marker Dekker, New York, p 4p
Cai F, Yu G, Wang P, Wei Z, Fu L, Shen Q, Chen W (2013) Harzianolide, a novel plant growth regulator and systemic resistance elicitor from Trichoderma harzianum. Plant Physiol Biochem 73:106-113

Carreres RGT, Sendra J, Ballesteros R, Fernández Valiente E, Quesada A, Nieva M, Leganés $F$ (1996) Effect of nitrogen rates on rice growth and biological nitrogen fixation. J Agric Sci 127:295-302

Chowdappa P, Kumar SPM, Lakshmi MJ, Upreti KK (2013) Growth stimulation and induction of systemic resistance in tomato against early and late blight by Bacillus subtilis OTPB1 or Trichoderma harzianum OTPB3. Biol Control 65:109-117

Contreras-Cornejo HA, Macías-Rodríguez L, Cortés-Penagos C, López-Bucio J (2009) Trichoderma virens, a plant beneficial fungus, enhances biomass production and promotes lateral root growth through an auxin-dependent mechanism in arabidopsis. Plant Physiol 149:1579-1592

Doni F, Al-Shorgani NKN, Tibin EMM, Abuelhassan NN, Anizan I, Che Radziah CMZ, Wan Mohtar WY (2013) Microbial involvement in growth of paddy. Curr Res J Biol Sci 5(6):285-290

Doni F, Anizan I, Che Radziah CMZ, Salman AH, Rodzihan MH, Wan Mohtar WY (2014) Enhancement of rice seed germination and vigour by Trichoderma spp. Res J App Sci Eng Technol 7(21): (in press)

Druzhinina IS, Kopchinsky AG, Kubicek CP (2006) The first 100 Trichoderma species characterized by molecular data. Mycoscience 47:55-64. doi:10.1007/ s10267-006-0279-7

Fu Y, Zheng-wei L, Zhi-chun W, Yuan C (2008) Relationship between diurnal changes of net photosynthetic rate and influencing factors in rice under saline sodic stress. Rice Sci 15(2):119-124

Habibah J, Lee PT, Khairiah J, Ahmad MR, Fouzi BA, Ismail BS (2011) Speciation of heavy metals in paddy soils from selected areas in Kedah and Penang, Malaysia. African J Biotechnol 10(62):13505-13513

Harman GE (2006) Overview of mechanisms and uses of Trichoderma spp. Phytopathol. doi:10.1094/PHYTO-96-0190

Harman GE, Petzoldt R, Comis A, Chen J (2004) Interactions between Trichoderma harzianum strain T22 and maize inbred line Mo17 and effect of this interaction on diseases caused by Pythium ultmum and Colletotricum graminicola. Phytopathol 94(2):147-153

Jiang X, Geng A, He N, Li Q (2011) New Isolate of Trichoderma viride strain for enhanced cellulolytic enzyme complex production. J Biosci Bioeng 111:121-127

John RP, Tyagi RD, Prévost D, Brar SK, Pouleur S, Surampalli RY (2010) Mycoparasitic Trichoderma viride as a biocontrol agent against Fusarium oxysporum f. sp. adzuki and Pythium arrhenomanes and as a growth promoter of soybean. Crop Prot 29:1452-1459

Khairiah J, Azie RR, Habibah J, Zulkifle I, Ismail BS (2013) Heavy metal content of paddy plants in Langkawi, Kedah, Malaysia. Aust J Basic Appl Sci 7(2):123-127

Li X, Bu N, Li Y, Ma L, Xin S, Zhang L (2012) Growth, photosynthesis and antioxidant responses of endophyte infected and non-infected rice under lead stress conditions. J Hazard Mater 213:55-61. doi:10.1016/j. jhamat2012.01.052

Lorito M, Woo SL, Harman GE, Monte E (2010) Translational research on Trichoderma: from 'omics to the field. Annu Rev Phytopathol 48:395-517

Makino A (2011) Photosynthetic, grain yield, and nitrogen utilization in rice and wheat. Plant Physiol 155:125-129

Malik KA, Rakhshanda B, Mehnaz B, Rasul G, Mirza MS, Ali S (1997) Association of nitrogen-fixing, Plant-Growth-Promoting Rhizobacteria (PGPR) with Kallar grass and rice. Plant Soil 194:37-44

Martínez-Medina A, Roldán A, Albacete A, Pascual JA (2011) The Interaction with Arbuscular Mycorrhizal Fungi or Trichoderma harzianum alters the shoot hormonal profile in melon plants. Phytochemistry 72:223-229. doi:10.1016/j. phytochem.2010.11.008

Micheal JSAS, Juraimi AS, Selamat A, Man A, Anwar MP, Uddin MK (2013) Critical period of weed control in aerobic rice system. AJCS 7(5):665-673

Mishra A, Salokhe VM (2011) Rice growth and physiological responses to SRI water management and implications for crop productivity. Paddy Water Environ 9:41-52. doi:10.1007/s10333-010-0240-4

Morsy EM, Abdel-Kawi KA, Khalil MNA (2009) Efficiency of Trichoderma viride and Bacillus subtilis as biocontrol agents gainst Fusarium solani on tomato plants. Egypt J Phytopathol 37(1):47-57

Nawrocka J, Malolepsza U (2013) Diversity in plant systemic resistance induced by Trichoderma. Biol Control 67:149-156. doi:10.1016/j.biocontrol.2013.07.005 Neumann B, Laing M (2006) Trichoderma: An Ally in the Quest for Soil System Sustainability. In: Uphoff N, Fernandes E, Herren H, Husson O, Laing M, Palm 
C, Pretty J, Sanchez P, Sanginga N, Thies J (eds) Biological Approaches to Sustainable Soil System. Taylor \& Francis, Boca Raton, FL, pp 491-500

Pedraza RO, Bellone CH, de Bellone SC, Sorte PMFB, dos Santos Teixeira KR (2009) Azospirillum Inoculation and Nitrogen Fertilization Effect on Grain Yield and on the Diversity of Endophytic Bacteria in the Phyllosphere of Rice Rainfed Crop. European J Soil Biol 45:36-43

Porras M, Barrau C, Romero F (2007) Effects of soil solarization and Trichoderma on strawberry production. Crop Prot 26:782-787

Raman J (2012) Response of Azotobacter, Pseudomonas and Trichoderma on Growth of Apple Seedling. International Conference on Biological and Life Sciences IPCBEE, IACSIT Press, Singapore

Saba HDV, Manisha M, Prashant KS, Farham H, Tauseff A (2012) Trichoderma - a promising plant growth stimulator and Biocontrol agent. Mycosphere. doi:10.5943/mycosphere/3/4/14

Sakthivel N, Gnanamanickam SS (1987) Evaluation of Pseudomonas fluorescens for suppression of sheath rot disease and for enhancement of grain yields in rice (Oryza sativa L.). Appl Environ Microbiol 53:2056-2059

Samuels GJ (1996) Trichoderma: a review of biological systemics of the genus. Mycol Res 100(8):923-935

Saravanakumar K, Shanmuga Arasu V, Kathiresan K (2013) Effect of Trichoderma on soil phosphate solubilization and growth improvement of Avicennia marina. Aquat Bot 104:101-105

Shanmugaiah V, Balasubramanian N, Gomathinayagam S, Manoharan PT, Rajendran A (2009) Effect of single application of Trichoderma viride and Pseudomonas fluorescens on growth cotton plants. African J Agri Res 4(11):1220-1225

Shukla N, Awasthi RP, Rawat L, Kumar J (2012) Biochemical and physiological responses of rice (Oryza sativa L.) as influenced by Trichoderma harzianum under drought stress. Plant Physiol Biochem 54:78-88

Tchameni SN, Ngonkeu MEL, Begoude BAD, Wakam Nana L, Fokom R, Owona AD, Mbarga JB, Tchana T, Tondje PR, Etoa FX, Kuaté J (2011) Effect of Trichoderma asperellum and Arbuscular Mycorrhizal Fungi on Cacao growth and resistance against black pod disease. Crop Prot 30:1321-1327. doi:10.1016/j.cropro.2011.05.003

Thakur M, Sohal BS (2013) Role of elicitors in inducing resistance in plants against pathogen infection: a review. ISRN Biochem :1-10. doi:10.1155/2013/762412

Thakur AK, Uphoff N, Antony E (2010) An assessment of physiological effects of system of rice intensification (sri) practices compared with recommended rice cultivation practices in india. Cambridge J 46(1):77-98

Vargas WC, Mandawe JC, Kenerley CM (2009) Plant-derived sucrose is a key element in the symbiotic association between Trichoderma virens and maize plants. Plant Physiol 151:792-808

Viterbo A, Landau U, Kim S, Chernin L, Chet I (2010) Characterization of AAC deaminase from the biocontrol and plant growth-promoting agent Trichoderma asperellum T203. FEMS Microbiol Lett 305:42-48

Yadav SK (2010) Heavy metals toxicity in plants: an overview on the role of glutathione and phytochelatins in heavy metal stress tolerance of plants. S Afr J Bot 76:167-179. doi:10.1016/j.sajb.2009.10.007

Yap DW, Adezrian J, Khairiah J, Ismail BS, Ahmad-Mahir R (2009) The uptake of heavy metals by paddy plants (Oryza sativa) in Kota Marudu, Sabah, Malaysia. Am Eurasian J Agric Environ Sci 6(1):16-19

doi:10.1186/s13568-014-0045-8

Cite this article as: Doni et al:: Physiological and growth response of rice plants (Oryza sativa L.) to Trichoderma spp. inoculants. AMB Express

2014 4:45.

\section{Submit your manuscript to a SpringerOpen ${ }^{\circ}$ journal and benefit from:}

- Convenient online submission

- Rigorous peer review

- Immediate publication on acceptance

- Open access: articles freely available online

- High visibility within the field

- Retaining the copyright to your article

Submit your next manuscript at $\gg$ springeropen.com 